\title{
Development of probiotic gummy candy using the indigenous Lactobacillus plantarum Dad-13 strain; evaluation of its gastrointestinal resistance and shelf- life prediction
}

\author{
${ }^{1,2}$ Kamil, R.Z., ${ }^{1}$ Fadhila, F.H., ${ }^{1}$ Rachmasari, A.D., ${ }^{1}$ Murdiati, A., ${ }^{3}$ Juffrie, M. and \\ $1,2, *$ Rahayu, E.S. \\ ${ }^{I}$ Department of Food and Agricultural Product Technology, Faculty of Agricultural Technology, \\ Universitas Gadjah Mada, Jl. Flora No 1 Bulaksumur, Yogyakarta 55281, Indonesia \\ ${ }^{2}$ Center for Food and Nutrition Studies, Universitas Gadjah Mada, Jl. Teknika Utara Barek, Yogyakarta \\ 55281, Indonesia \\ ${ }^{3}$ Faculty of Medicine, Public Health and Nursing, Universitas Gadjah Mada, Jl. Farmako, Senolowo, Sekip \\ Utara, Yogyakarta 55281, Indonesia
}

\begin{abstract}
Article history:
Received: 31 December 2020

Received in revised form: 8 February 2021

Accepted: 29 April 2021

Available Online: 30 October 2021
\end{abstract}

Keywords:

Gummy probiotic,

Probiotics,

Lactobacillus plantarum Dad -13 ,

Gastrointestinal resistance,

Shelf-life

DOI:

https://doi.org/10.26656/fr.2017.5(5).731

\begin{abstract}
Nowadays, functional food especially probiotic products have gained more interest, and gummy candy L. plantarum Dad-13 is an innovation. However, the efficacy of probiotics relies on their viable cells and resistance in the gastrointestinal tract. Therefore, this research aimed to evaluate the gastrointestinal resistance and probiotic cells' shelf life and investigate gummy probiotics' characteristics. A market survey was carried to understand the consumer's knowledge on the health benefit of probiotics and their product, also intend to buy the product. Gastrointestinal simulation with pepsin and the pancreatic enzyme was conducted to evaluate the gastrointestinal tract's probiotic resistance, probiotic shelf life was evaluated with the Accelerated Shelf-life Test (ASLT). Proximate analysis was carried out according to the Association of Official Analytical Chemists (AOAC), and physical characteristics were analysed before and after 90 days of storage at $4^{\circ} \mathrm{C}$. The result showed that the supplementation of L. plantarum Dad-13 in the gummy probiotic had an excellent survival during gastrointestinal system simulation with the predicted shelf life was 75.17 days or 2.5 months at $4^{\circ} \mathrm{C}$ of storage. However, the moisture content of gummy probiotics was more than $20 \%$. Considering the survival of $L$. plantarum Dad13 during gastrointestinal simulation, it can be concluded that gummy probiotics can be used as a carrier for L. plantarum Dad-13.
\end{abstract}

\section{Introduction}

In recent years, functional foods have gained increased interest. Functional food is a type of dietary item that is pleasant in the sensory attributes and provides essential nutrition and brings health benefits. Several functional ingredients are typically added to make functional foods, ranging from the phenolic compound, resistant starch, insoluble dietary fibre, prebiotic, to even a live microorganism, which was probiotic (Abuajah et al., 2015; Gul et al., 2016). Probiotic is a live microorganism that, when consumed in an adequate amount, will give health benefits to the host (Food and Agriculture Organization/World and Organization, 2002). Several health benefits of probiotics are known to maintain gastrointestinal health, improve immune response, inhibit pathogen colonisation in the colon, and produce short-chain fatty acid (Kechagia et al., 2013).

Of many probiotics, L. plantarum Dad-13 is worth mentioning. L. plantarum Dad-13 is an indigenous probiotic isolated from a spontaneously fermented buffalo milk called dadih. The strain has been characterised for its probiotic potentials such as antimicrobial activity and its resistance in gastrointestinal in vitro (Rahayu et al., 2015). Molecular analysis showed that the strain belonged to L. plantarum species (Rahayu et al., 2015), and a safety assessment of L. plantarum Dad-13 using Sprague Dawley rats demonstrated that no translocation was observed in the rats' organ and blood (Rahayu et al., 2019). Indeed, several clinical trials showed that L. plantarum Dad-13 could survive in the gastrointestinal tract (Rahayu et al., 
2016; Banin et al., 2019; Rahayu et al., 2019). Lactobacillus plantarum Dad-13 has anti-diarrhoea and immune-modulator properties (Nurliyani et al., 2015; Tari and Handayani, 2015), and it is considered an intracellular uricase producer (Handayani et al., 2017).

For as much as the background mentioned above, $L$. plantarum Dad-13 has a considerable potential to be applied in food products other than yoghurt and other fermented foods. Supplementation of $L$. plantarum Dad13 into food products has been conducted in several studies, such as in yoghurt, yoghurt with purple sweet potato extract, fermented milk, and tape ketan (fermented sticky rice) (Tari et al., 2016; Utami et al., 2016; Rahayu et al., 2016; Pamungkaningtyas et al., 2018). However, all of those probiotic products are limited to fermented food. Consumers prefer food that is not only nutrient-enriched but also convenient (easy to handle).

The number of viable probiotics is essential to give health benefits, and a probiotic product should have viable cells count of $10^{6}-10^{7} \mathrm{CFU} / \mathrm{g}$ or $\mathrm{mL}$ at the end of the expired date for their efficacy (Barbosa et al., 2015). These factors make predicting their shelf-life crucial. The accelerated test is one of the methods to predict the shelf-life in a short-term test under harsh conditions by extrapolating the kinetic parameter and the storage environment. L. plantarum Dad-13 supplemented with gummy probiotics should retain its viable cells against gastrointestinal conditions to colonise in the colon. Therefore, this research aimed to develop a new indigenous gummy probiotic L. plantarum Dad-13, as a carrier of the probiotic cell. With that in mind, resistance in the gastrointestinal tract, probiotic cells' shelf-life prediction, and gummy probiotics' physicochemical characteristics were evaluated.

\section{Materials and methods}

\subsection{Survey of consumer's behaviour and acceptance}

The descriptive questionnaire was designed to understand consumers' behaviour, mainly knowledge on the health benefit of probiotics and their products. A consumer survey was conducted between teenagers and adults, which represents the target market for probiotic products. Each right answer was scored as 1, while each wrong answer was scored 0 , which then divided into three categories: good ( $>75 \%$ of the right answer), fair $(50-75 \%$ of the right answer), and low ( $<50 \%$ of the right answer). Consumer's interest in the indigenous gummy probiotic product was asked as "yes" and "no" answers.

\subsection{Bacterial used in this study}

Skim milk powder containing L. plantarum Dad-13 was obtained from the Centre for Food and Nutrition Studies, Universitas Gadjah Mada.

\subsection{Gummy probiotic production}

The production of gummy probiotics was modified from Lele et al. (2018). The formula consisted of bovine gelatine (11 g), sucrose (20 g), glucose syrup (10 g), water $(20 \mathrm{~g})$, and skim milk powder containing $L$. plantarum Dad-13 (5 g), with the initial cell counts $7.58 \times 10^{9} \mathrm{CFU} / \mathrm{g}$. In brief, the gelatine was soaked with water for 15 mins to bloom. The sugar solution was prepared by diluting glucose syrup, sucrose, and water by heating at $115-120^{\circ} \mathrm{C}$ for 15 mins. After that, the sugar solution and bloomed gelatine were mixed until there was no lump, and then the mixture was cooled until it reached $40^{\circ} \mathrm{C}$. Before the addition of probiotics, skim milk powder containing L. plantarum Dad-13 was dissolved with water and mixed into a candy mixture at $40^{\circ} \mathrm{C}$. The citric acid $(0.1 \mathrm{~g})$ was incorporated into the candy mixture at the end of the process. Flavour agents could be added at the desired amount. The candy mixture was then poured into a mould and set at room temperature for 30 mins and continued in a chiller. Once it had finished, the gummy probiotic was packed and sealed into an aluminium bag and was kept dry until the analysis.

\subsection{Microbial count}

The viable cells of $L$. plantarum Dad-13 were count by pour plate method. The samples $(1 \mathrm{~g})$ were diluted into $9 \mathrm{~mL}$ saline water $(0.85 \% \mathrm{NaCl}, \mathrm{w} / \mathrm{v})$ and homogenised with a stomacher followed by serial dilution. At appropriate dilution series, $1 \mathrm{~mL}$ of suspension was plated on De Man, Rogosa, and Sharpe (MRS) agar medium (Oxoid) and incubated at $37^{\circ} \mathrm{C}$ for two days. The counted L. plantarum Dad-13 was then expressed as $\mathrm{CFU} / \mathrm{g}$ samples.

\subsection{Gastrointestinal simulations}

The survival of probiotic L. plantarum Dad-13 in the simulated gastrointestinal tract was analysed in vitro according to Tokatl et al. (2015) with modification. Briefly, for the gastric simulation, the samples $(1 \mathrm{~g})$ were incubated in a gastric solution at $37^{\circ} \mathrm{C}$ for $2 \mathrm{hrs}$, which was prepared by suspending $3 \mathrm{mg} / \mathrm{mL}$ pepsin (SigmaAldrich; P 7000$)$ into sterile saline water $(0.85 \% \mathrm{NaCl}$, $\mathrm{w} / \mathrm{v}$ ) and adjusting the $\mathrm{pH}$ to 2.5. Meanwhile, for the intestinal simulation, the samples were incubated in an intestinal solution at $37^{\circ} \mathrm{C}$ for $4 \mathrm{hrs}$, which was prepared by suspending $1 \mathrm{mg} / \mathrm{mL}$ pancreatic (Sigma-Aldrich; $\mathrm{P} 7545)$ and $0.3 \%(\mathrm{w} / \mathrm{v})$ bile salt into sterile saline water $(0.85 \% \mathrm{NaCl}, \mathrm{w} / \mathrm{v})$ and adjusting the $\mathrm{pH}$ to 8 . The viable count of L. plantarum Dad-13 was determined before and at each hour interval of incubation. 


\subsection{Probiotic shelf-life prediction by accelerated test}

Packed gummy probiotic samples were stored at four different temperatures $\left(4,11,30\right.$, and $\left.37^{\circ} \mathrm{C}\right)$. The cell viability of $L$. plantarum Dad-13 was counted at intervals $0,2,4,6,8,12,16$, and 22 days for samples that were incubated at 30 and $37^{\circ} \mathrm{C}$. Meanwhile, at intervals $0,2,4,6,8,12,16,22,28$, and 34 days was applied for samples were incubated at 4 and $11^{\circ} \mathrm{C}$. The viable count was fitted to zero as well as to the firstorder reaction equation model, as shown in equations 1 and 2 , respectively.

$\mathrm{N}=\mathrm{N}_{\mathrm{o}}-\mathrm{k}_{\mathrm{t}}$

$\ln \mathrm{N}=\ln \mathrm{N}_{\mathrm{o}}-\mathrm{k}_{\mathrm{t}}$

$\mathrm{N}_{\mathrm{o}}$ is the initial cells count (CFU/g), while $\mathrm{N}$ is viable cells count in everyday storages $(\mathrm{CFU} / \mathrm{g})$. On the other hand, ${ }_{t}$ is a time of storage, and $\mathrm{k}$ is the inactivation rate constant $\left(\mathrm{day}^{-1}\right)$. For estimating the probiotics shelflife, the inactivation rate at each incubation temperature was plotted to obtain the Arrhenius equation, as shown in equation 3 .

$\ln \mathrm{k}=\ln \mathrm{k}_{0}-\mathrm{Ea} / \mathrm{RT}$

$\mathrm{Ea}$ is the activation energy ( $\mathrm{kcal} / \mathrm{mol})$, while $\mathrm{R}$ and T is the universal gas constant $\left(\mathrm{R}=1.987 \mathrm{cal} \cdot \mathrm{mol}^{-1} \cdot \mathrm{k}^{-1}\right)$, and the absolute temperature $\left({ }^{\circ} \mathrm{K}\right)$, in turn.

Packed gummy probiotics, which were incubated at $4^{\circ} \mathrm{C}$, were collected and analysed for the viable cells at a regular interval of 10 days until the viable cells reached the limit dose of probiotic $1 \times 10^{7} \mathrm{CFU} / \mathrm{g}$.

\subsection{Physicochemical analysis}

Proximate analysis was done by using the standard procedure of AOAC (2005). The gummy probiotic energy content was calculated using Atwater's conversion factors (Araro et al., 2020). Physical characteristics of gummy probiotics were analysed before and after 90 days of storage at $4^{\circ} \mathrm{C}$. The colour parameters $\left(\mathrm{L}^{*}, \mathrm{a}^{*}\right.$, and $\left.\mathrm{b}^{*}\right)$ were measured using chromameter (Minolta CR-310), and $\mathrm{a}_{\mathrm{w}}$ was measured using $\mathrm{a}_{\mathrm{w}}$ meter (pa $\mathrm{wit}$ ). Meanwhile, the texture of

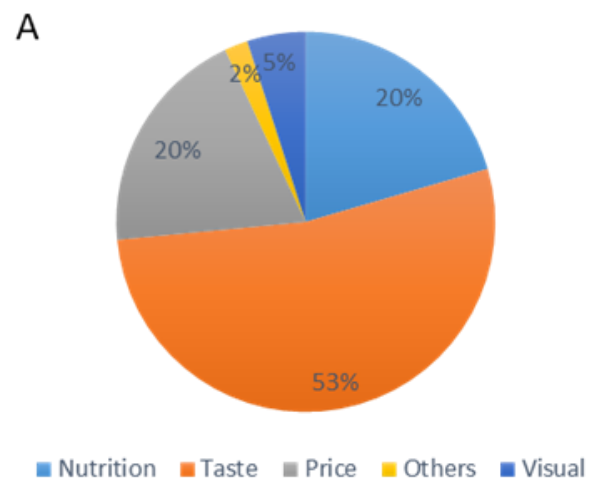

gummy probiotics was measured using a texture analyser (NEXYGEN plus).

\subsection{Statistical analysis}

Any significant difference in all samples was evaluated with one-way ANOVA followed by the Duncan Multiple Range Test. A paired t-test was performed to assess any significant difference in physical characteristics after storage. All statistical analysis was performed by IBM SPSS Statistic 24 confidentially ( $p$ value $<0.05$ ).

\section{Results and discussion}

\subsection{Consumer's behaviour and acceptance}

A total of 200 respondents (age:18-24 years old) filled out the questionnaire. As shown in Figure 1, aside from the sensory aspect, the nutritional value was one of the considerable aspects of selecting food. More than half of respondents (62\%) had good knowledge regarding probiotics, with acceptance and intention to buy gummy probiotics reach for $92 \%$ of respondents. The probiotic consumption trend is inspired by the Balkan region, which has a longevity life span due to their habit of consuming fermented milk. The trend is widespread and has become a new lifestyle, particularly with the role of aggressive advertising in the media. Besides that, awareness of healthy lifestyles among the community has dramatically increased. According to Lerner et al. (2019), citing from global market analysts, probiotics' global market size is predicted to exceed 3 billion US dollars by 2024. Therefore, with the growth of the probiotics market, and consumer knowledge regarding probiotics, the development of indigenous gummy probiotics is possible to fulfil the demand in the probiotic market.

\subsection{Resistance to the gastrointestinal simulations}

An adequate amount of probiotic cells in a probiotic product does not guarantee its resistance throughout the gastrointestinal system. The initial cell count of the gummy probiotic was $5.88 \times 10^{8} \mathrm{CFU} / \mathrm{g}$. As seen in Figure 2 (a), after $2 \mathrm{hrs}$ of incubation at the simulated

B

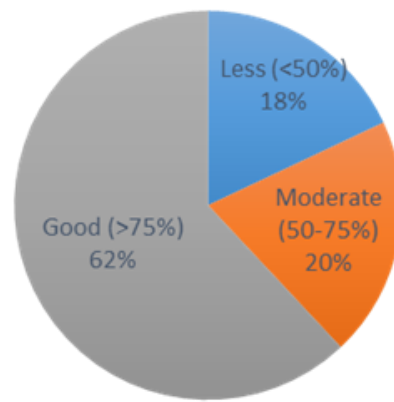

a Less $(<50 \%) \quad$ Moderate $(50-75 \%) \quad$ Good $(>75 \%)$

Figure 1. Consumers behaviour. (A) Consideration for selecting food. (B) Consumer's knowledge regarding probiotic 
A

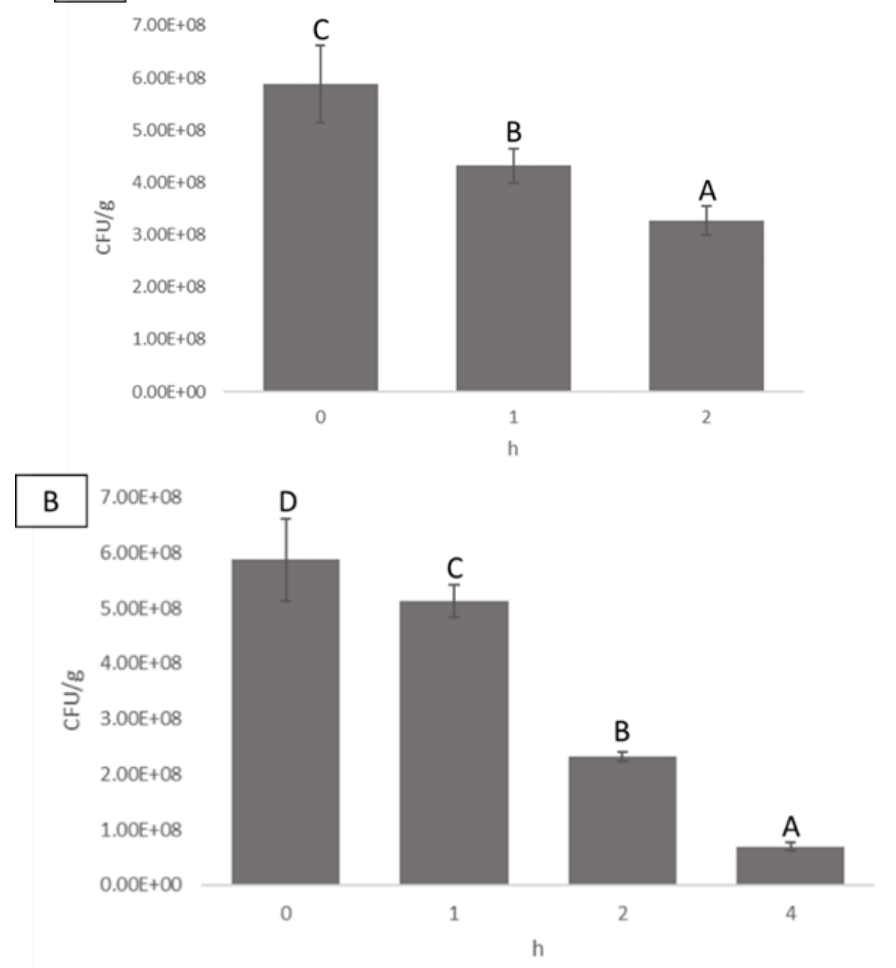

Figure 2. Gastrointestinal simulations of L. plantarum Dad13. (A) Resistance in simulated gastric solution. (B) Resistance in simulated intestinal solution. Values are presented as mean $\pm \mathrm{SD}, \mathrm{n}=2$. Different letters are significantly different $(\mathrm{p}<0.05)$ by one-way ANOVA followed by Duncan Multiple Range Test.

gastric juice, the final viable cell count was $3.28 \times 10^{8}$ $\mathrm{CFU} / \mathrm{g}$ (44.26\% reduction from the initial cells). A significant difference was observed at the simulated intestinal after 4-hour incubation, which was $6.98 \times 10^{7}$ CFU/g (88.13\% reduction) from initial cells (Figure 2B).

Gummy probiotic can be classified as a hydrogel due to its main ingredient (i.e., gelatine, agar, and pectin). Protein-based hydrogels are applicable for delivery systems, especially nutraceuticals, due to their excellent functional properties, low toxicity, and high nutrition value (Abaee et al., 2017). According to Young et al. (2005), gelatine-based controlled-release systems have been developed because their tailored electrical and physical properties depend on the operation process. Several studies have reported that gummy candy can be used as a carrier for bovine colostrum, essential oils, and also probiotics (Bartkiene et al., 2018; Lele et al., 2018). In addition, gelatine also acts as a protective agent in delivery systems (Santoro et al., 2014). Interaction between gelatine and milk protein within the candy mixture is expected to occur since those polymers carry an opposite charge (Pang et al., 2013). According to Pang et al. (2015), gelatin and skim milk protein will increase the gel's firmness. Therefore, the diffusion of a gastric and intestinal solution to contact with probiotic cells will be delayed.
Powder L. plantarum Dad-13 was obtained with microencapsulation by a freeze-dried process using skim milk as a protectant. Microencapsulated probiotics had more stable viability against the harsh condition than free cell form, as reported in other studies (Liao et al., 2017; Moayyedi et al., 2018; Kamil et al., 2020). The microencapsulation process's role is to immobilise probiotic cells within a matrix and protect against harsh conditions (Anal and Singh, 2007; Abd El-Salam and ElShibiny, 2015; Eckert et al., 2017). The probiotic gummy candy can retain its minimum viable cells at $10^{7}$ $\mathrm{CFU} / \mathrm{g}$ in gastrointestinal simulation. Therefore, it can be estimated that the viable cells of $L$. plantarum Dad-13 are high enough to colonise in the colon.

\subsection{Viable cells count of probiotic at different temperature}

As seen in Figure 3, the initial cell count of $L$. plantarum Dad-13 in gummy probiotics was $7.80 \times 10^{8}$ $\mathrm{CFU} / \mathrm{g}$. A loss of viable cell count had been observed at the time of storage. After 22 days of storage, gummy probiotics stored at 30 and $37^{\circ} \mathrm{C}$ had a higher reduction of the counted viable cell, from the initial cells to $6.50 \times 10^{3}$ and $1.52 \times 10^{3} \mathrm{CFU} / \mathrm{g}$, respectively. In addition, gummy probiotic, which was stored at $11^{\circ} \mathrm{C}$, had a viable cell count of $2.50 \times 10^{7} \mathrm{CFU} / \mathrm{g}$ after 34 days. Meanwhile, storing at $4^{\circ} \mathrm{C}$, the gummy probiotic had more stable viable cells, which count $1.16 \times 10^{8} \mathrm{CFU} / \mathrm{g}$.

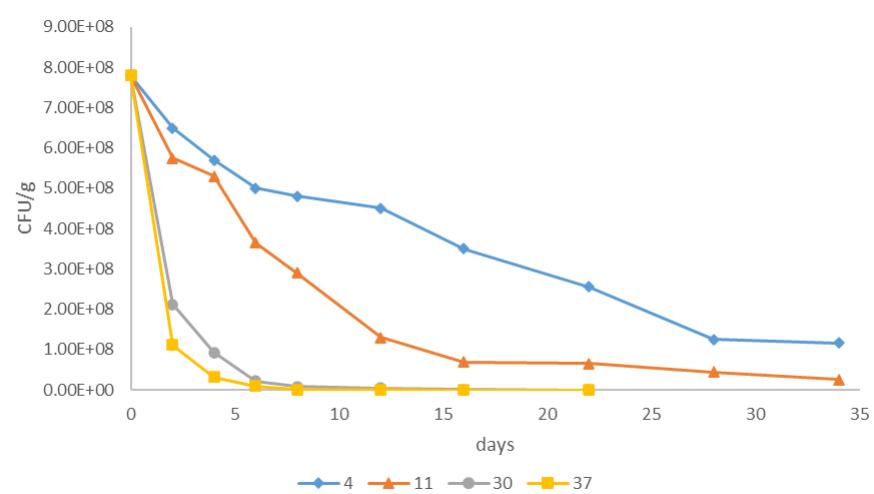

Figure 3. Changes in probiotic viability at different temperatures. Values are presented as mean $\pm \mathrm{SD}, \mathrm{n}=2$.

Lestari et al. (2020) reported a similar observation, where good stability of L. acidophilus IFO 13951 and Bifidobacterium longum ATCC 15707 in gummy probiotic is achieved at $4^{\circ} \mathrm{C}$ of storage. Conversely, an expressive decrease of viable cells was observed at storage over $25^{\circ} \mathrm{C}$, and it is reported in other research (Klayraung et al., 2009; Nagashima et al., 2013; Lestari et al., 2020). Another observation by Lele et al. (2018) showed that the use of gelatine as an ingredient of gummy probiotics gives good stability during storage.

High temperature is one of the considered factors affecting probiotic stability, besides $\mathrm{pH}$, water activity, 
chemical compound, and oxygen content (Gueimonde and Sánchez, 2012). Also, gelatine as hydrogel could be affected by temperature. According to Ullah et al. (2015), at high temperatures, hydrogel's structure will dissociate and swell due to the breaking of the hydrogen bonds. It causes the inability to protect the probiotic cells. On the contrary, at low temperatures, a complex structure of gelatine hydrogel is formed by hydrogen bonds and entraps the probiotic cells to become more settled.

\subsection{Prediction of probiotic shelf-life}

The change of food characteristics follows either zero or first-order reaction (Calligaris et al., 2019). Therefore, the changes in the viable cells are plotted into zero and first-order reactions. As seen in Table 1, the first-order reaction has excellent linearity compared to the zero-order. Therefore, it will be used further in the Arrhenius equation.

The slope of the equation refers to the inactivation rate of probiotic cells stored at different temperatures. Increasing the temperature of incubation aligns with a high inactivation rate. It shows that the accelerated test's kinetic model is temperature-dependent, and the same result was observed in other research (Achour et al., 2001; Park et al., 2018; Zhi et al., 2018; Li et al., 2019). The $\ln$ value of the inactivation rate was plotted with reciprocal absolute temperature, which the Arrhenius equation will obtain. The obtained equation was further used to estimate the shelf-life according to the first-order reaction in equation 4 .

$\mathrm{t}_{\mathrm{s}}=\ln (\mathrm{No}-\mathrm{Nt}) / \mathrm{k}$

$t_{s}$ is estimated shelf-life, $N_{o}$ is the initial cells count (CFU/g), $\mathrm{N}_{\mathrm{t}}$ is the viable limit cells at the end of storage $\left(10^{7} \mathrm{CFU} / \mathrm{g}\right)$, and $\mathrm{k}$ is the inactivation rate constant (day $\left.{ }^{1}\right)$.

As seen in Table 2, the estimated shelf-life of viable L. plantarum Dad-13 at $4,11,30$, and $37^{\circ} \mathrm{C}$ was as follows: $75.17,43.49,11.19$, and 7.07 days, respectively. According to the estimated shelf-life, cold storage $\left(4^{\circ} \mathrm{C}\right)$ was recommended to maintain the viable cells of probiotic L. plantarum Dad-13. However, the observed shelf-life to reach the minimal count of viable cells at $1.9 \times 10^{7} \mathrm{CFU} / \mathrm{g}$ was 90 days at $4^{\circ} \mathrm{C}$ of storage or with a relative error of $16.48 \%$. Even though the incubation condition was maintained stable during storage, food deterioration is more complicated. Other factors, such as humidity, water activity, and packaging materials, may affect the rate of food deterioration. Otherwise, the accelerated test can be applied as a model to predict the shelf-life of gummy probiotic L. plantarum Dad-13.

\subsection{Physicochemical characteristics of gummy probiotic L. plantarum Dad-13}

Physicochemical characteristics of gummy probiotics can be seen in Table 3. According to the Indonesian standard about gummy probiotics (SNI 3547.2-2008) (Badan Standardisasi Nasional, 2008), the maximum moisture content is $20 \%$. In this research, gummy probiotics' moisture content was higher than $20 \%$. Moisture content in gummy probiotics has a relation with the amount of the used gelatine (Susanty and Pujilestari, 2016). The more gelatine used, the more free water molecule will interact. Pang et al. (2015) reported that gelatine enhances water holding capacity in combination with skim milk protein, which may be the cause of high moisture content in gummy probiotics. The final moisture content of food determines its physical characteristics as well as its shelf-life. The lower the moisture content, the more rigid texture of gummy probiotics with a longer shelf-life (Ergun et al., 2010).

In line with the high moisture content, high water activity was also observed in gummy probiotics. In confectionery, water activity is an important parameter to describe microbiological and physical characteristics. According to Ergun et al. (2010), as a confectionery product, gummy candy has water activity in the range of $0.5-0.75$. Besides, in the modern confectionery factory, convection drying in tunnels or chambers is done after the moulding process (Delgado and Bañón, 2015). In gummy probiotic production, on the other hand, the drying process is not carried out. However, the ash content of gummy probiotic is within the SNI 3547.22008 standard.

Table 1. Linear regression equations for the estimated shelf-life

\begin{tabular}{|c|c|c|c|c|}
\hline \multirow{2}{*}{ Temperatures $\left({ }^{\circ} \mathrm{C}\right)$} & \multicolumn{2}{|c|}{ Zero-order reaction } & \multicolumn{2}{|c|}{ First-order reaction } \\
\hline & Linear Equations & $\mathrm{R}^{2}$ & Linear Equations & $\mathrm{R}^{2}$ \\
\hline 4 & $y=-1.82 \times 10^{7} x+6.69 \times 10^{8}$ & 0.9484 & $y=-0.0562 x+20.453$ & 0.9674 \\
\hline 11 & $y=-1.99 \times 10^{7} x+5.51 \times 10^{8}$ & 0.7466 & $y=-0.1022 x+20.28$ & 0.9487 \\
\hline 30 & $y=-2.23 \times 10^{7} x+3.35 \times 10^{8}$ & 0.3865 & $y=-0.4236 x+19.942$ & 0.9802 \\
\hline 37 & $y=-1.98 \times 10^{8} x+2.90 \times 10^{8}$ & 0.2995 & $y=-0.5734 x+19.613$ & 0.9785 \\
\hline
\end{tabular}

Linear equations of zero-order reaction are obtained from reciprocal incubation time in days (X) and viable cells count in CFU/g (Y). While linear equations of the first-order reaction are obtained from reciprocal incubation time in days $(\mathrm{X})$ and viable cells count in $\ln \mathrm{CFU} / \mathrm{g}(\mathrm{Y})$ 
Table 2. Shelf-life predicted by ASLT

\begin{tabular}{ccccccccc}
\hline $\mathrm{T}\left({ }^{\circ} \mathrm{C}\right)$ & $\begin{array}{c}\ln \mathrm{k} \\
\left(\mathrm{day}^{-1}\right)\end{array}$ & Arrhenius equation & $\mathrm{R}^{2}$ & $\mathrm{~N}_{\mathrm{o}}(\mathrm{CFU} / \mathrm{g})$ & $\mathrm{N}_{\mathrm{t}}(\mathrm{CFU} / \mathrm{g})$ & $\mathrm{ESL}($ days $)$ & OSL (days) & $\mathrm{RE}(\%)$ \\
\hline 4 & -2.879 & & & & & 75.17 & 90 & 16.48 \\
11 & -2.281 & & & & & 43.49 & & \\
30 & -0.859 & $\mathrm{y}=-6149.7 \mathrm{x}+19.353$ & 0.9964 & $7.80 \times 10^{8}$ & $1 \times 10^{7}$ & 11.19 & & \\
37 & -0.556 & & & & & 7.07 & & \\
\hline
\end{tabular}

Arrhenius equation is obtained from the first order's inactivation rate reaction at different temperatures. ESL: Estimated shelflife; OSL: Observed shelf-life; RE: Relative error, between observed shelf-life and estimated shelf-life at $4^{\circ} \mathrm{C}$

Moreover, gummy probiotic has a milky white colour, as indicated in the value of $\mathrm{L}^{*}, \mathrm{a}^{*}, \mathrm{~b}^{*}$. The yellowish-white colour of gummy probiotics is due to the existence of skim milk as an ingredient in the making of candy. Also, for gummy probiotics, the texture is one of the primary determinants for its quality. In this research, after 90 days of storage at $4^{\circ} \mathrm{C}$, a significant difference was observed in the gummy probiotic's hardness and gumminess. An increment of hardness gum candy was also observed by Csima et al. (2014) during storage at several temperatures. The increment of hardness and gumminess of gummy probiotics may be due to a complex inner structure of gelatine that formed during cold storage (Ullah et al., 2015).

Table 3. Physicochemical characteristics of gummy probiotic

\begin{tabular}{lcc}
\hline \multicolumn{3}{c}{ Proximate Content } \\
\hline Moisture (\%) & $27.83 \pm 0.21$ \\
Ash (\%) & $0.61 \pm 0.01$ \\
Crude fat (\%) & $0.08 \pm 0.01$ \\
Crude protein ${ }^{*}(\%)$ & $16.38 \pm 0.08$ \\
Available carbohydrate (\%) & $55.12 \pm 0.12$ \\
Energy (Kcal/100 g) & $286.66 \pm 0.88$ \\
\hline \multicolumn{3}{c}{ Physical characteristics } \\
\hline \multicolumn{3}{c}{ Before } \\
\hline Colour & After \\
\hline L $^{*}$ & $56.10 \pm 0.90$ & $56.07 \pm 1.23$ \\
a $^{*}$ & $-1.45 \pm 0.16$ & $-1.38 \pm 0.22$ \\
b $^{*}$ & $11.93 \pm 0.34$ & $12.32 \pm 0.42$ \\
\hline Texture & \\
\hline Hardness (N) & $4.37 \pm 0.37$ \\
Gumminess (N) & $4.07 \pm 0.36$ & $5.38 \pm 0.70^{\gamma}$ \\
Chewiness (N) & $3.84 \pm 0.35$ & $4.20 \pm 0.61^{\gamma}$ \\
\hline aw & $0.81 \pm 0.01$ & $0.82 \pm 0.01$ \\
\hline
\end{tabular}

Values are presented as means $\pm \mathrm{SD}, \mathrm{n}=2$.

\# conversion factor: 6.25 ; ${ }^{\gamma}$ significantly different $(\mathrm{p}<0.05)$ by paired t-test.

\section{Conclusion}

A non-fermented food product of indigenous probiotic L. plantarum Dad-13 in the form of gummy probiotic was developed and it has a good acceptance according to consumer's survey. In vitro analysis showed that L. plantarum Dad-13 supplemented into gummy probiotics has a good survival during gastrointestinal tract simulation, which means that gummy probiotics can be used as a carrier to deliver probiotics. According to the result of shelf-life prediction, cold storage $\left(4^{\circ} \mathrm{C}\right)$ is preferable to maintain the probiotic cells with no major changes in the physical characteristics of gummy probiotics.

\section{Conflicts of interest}

The authors declare that there is no conflict of interest regarding the publication of this paper.

\section{Acknowledgment}

This work was supported by the Ministry of Research, Technology and Higher Education of the Republic of Indonesia (KEMENRISTEK-DIKTI) under PMDSU (Pendidikan Magister meuju Doktor untuk Sarjana Unggul) batch 3 programme. Grant number: 2974/UN1.DITLIT/DIT-LIT/LT/2019.

\section{References}

Abaee, A., Mohammadian, M. and Jafari, S.M. (2017). Whey and soy protein-based hydrogels and nanohydrogels as bioactive delivery systems. Trends in Food Science and Technology, 70, 69-81. https:// doi.org/10.1016/j.tifs.2017.10.011

Abd El-Salam, M.H. and El-Shibiny, S. (2015). Preparation and properties of milk proteins-based encapsulated probiotics: a review. Dairy Science and Technology, 95(4), 393-412. https://doi.org/10.1007/ s13594-015-0223-8

Abuajah, C.I., Ogbonna, A.C. and Osuji, C.M. (2015). Functional components and medicinal properties of food: a review. Journal of Food Science and Technology, 52(5), 2522-2529. https:// doi.org/10.1007/s13197-014-1396-5

Achour, M., Mtimet, N., Cornelius, C., Zgouli, S., Mahjoub, A., Thonart, P. and Hamdi, M. (2001). Application of the accelerated shelf life testing method (ASLT) to study the survival rates of freezedried Lactococcus starter cultures. Journal of Chemical Technology and Biotechnology, 76(6), 624 -628. https://doi.org/10.1002/jctb.427

Anal, A.K. and Singh, H. (2007). Recent advances in microencapsulation of probiotics for industrial 
applications and targeted delivery. Trends in Food Science and Technology, 18(5), 240-251. https:// doi.org/10.1016/j.tifs.2007.01.004

AOAC (Association of Official Analytical Chemists). (2005). Official Methods of Analysis. Arlington, USA: AOAC.

Araro, T., Gemechu, F., Wotango, A. and Esho, T. (2020). Chemical formulation and characterization of complementary foods from blend of orangefleshed sweet potato, brown teff, and dark red kidney beans. International Journal of Food Science, 2020, 4803839. https://doi.org/10.1155/2020/4803839

Badan Standardisasi Nasional. (2008). SNI 3547.2-2008 (Kembang gula-Bagian 2: Lunak). Jakarta, Indonesia: Badan Standardisasi Nasional-BSN.

Banin, M.M., Utami, T., Cahyanto, M.N., Widada, J. and Rahayu, E.S. (2019). Effects of consumption of probiotic powder containing Lactobacillus plantarum dad-13 on fecal bacterial population in school-age children in Indonesia. International Journal of Probiotics and Prebiotics, 14(1), 1-8. https://doi.org/10.37290/ijpp2641-7197.14:1-8

Barbosa, J., Borges, S., Amorim, M., Pereira, M.J., Oliveira, A., Pintado, M.E. and Teixeira, P. (2015). Comparison of spray drying, freeze drying and convective hot air drying for the production of a probiotic orange powder. Journal of Functional Foods, 17, 340-351. https://doi.org/10.1016/ j.jff.2015.06.001

Bartkiene, E., Ruzauskas, M., Lele, V., Zavistanaviciute, P., Bernatoniene, J., Jakstas, V., Ivanauskas, L., Zadeike, D., Klupsaite, D., Viskelis, P., Bendoraitiene, J., Navikaite-Snipaitiene, V. and Juodeikiene, G. (2018). Development of antimicrobial gummy candies with addition of bovine colostrum, essential oils and probiotics. International Journal of Food Science and Technology, 53(5), 1227-1235. https:// doi.org/10.1111/ijfs.13701

Calligaris, S., Manzocco, L., Anese, M. and Nicoli, M. C. (2019). Accelerated shelf life testing of foods. In Galanakis, C.M. (Ed.), Food Quality and Shelf Life 1st ed., p. 359-392. Chania, Greece: Academic Press. https://doi.org/10.1016/B978-0-12-8171905.00012-4

Csima, G., Várvölgyi, E. and Eszter Vozáry. (2014). Effect of non-ideal storage conditions on candy gum quality. Presented at International Conference of Agricultural Engineering. Zurich. Retrieved from website: https://pdfs.semanticscholar.org/ ea9d/2edbe2effe9316556ef58d14276a97575fa7.pdf? $\mathrm{ga}=2.130161679 .1011036068 .1606138725$ 88172159.1544671048
Delgado, P. and Bañón, S. (2015). Determining the minimum drying time of gummy confections based on their mechanical properties. CYTA - Journal of Food, 13(3), 329-335. https:// doi.org/10.1080/19476337.2014.974676

Eckert, C., Serpa, V.G., Felipe dos Santos, A.C., Marinês da Costa, S., Dalpubel, V., Lehn, D.N. and Volken de Souza, C.F. (2017). Microencapsulation of Lactobacillus plantarum ATCC 8014 through spray drying and using dairy whey as wall materials. $L W T$ - Food Science and Technology, 82, 176-183. https://doi.org/10.1016/j.lwt.2017.04.045

Ergun, R., Lietha, R. and Hartel, R.W. (2010). Moisture and shelf life in sugar confections. Critical Reviews in Food Science and Nutrition, 50(2), 162-192. https://doi.org/10.1080/10408390802248833

Food and Agriculture Organization/World Health Organization (2002). Guidelines for the Evaluation of Probiotics in Food. Joint FAO/WHO Working Group Report on Drafting Guidelines for the Evaluation of Probiotics in Food. Retrieved from WHO website: http://www.who.int/foodsafety/ fs_management/en/probiotic_guidelines.pdf

Gueimonde, M. and Sánchez, B. (2012). Enhancing probiotic stability in industrial processes. Microbial Ecology in Health and Disease, 23, 18562. https:// doi.org/10.3402/mehd.v23i0.18562

Gul, K., Singh, A.K. and Jabeen, R. (2016). Nutraceuticals and functional foods: the foods for the future world. Critical Reviews in Food Science and Nutrition, 56(16), 2617-2627. https:// doi.org/10.1080/10408398.2014.903384

Handayani, I., Utami, T., Hidayat, C. and Rahayu, E.S. (2017). Enhancement of an intracellular uricase produce by L. plantarum Dad-13 which has stability in gastrointestinal system. Research Journal of Microbiology, 12(3), 202-209. https:// doi.org/10.3923/jm.2017.202.209

Kamil, R.Z., Yanti, R., Murdiati, A., Jurffrie, M. and Rahayu, E.S. (2020). Microencapsulation of indigenous probiotic Lactobacillus plantarum Dad13 by spray and freeze-drying: strain-dependent effect and its antibacterial property. Food Research, 4(6), 2181-2189. https://doi.org/10.26656/fr.2017.4 (6). 280

Kechagia, M., Basoulis, D., Konstantopoulou, S., Dimitriadi, D., Gyftopoulou, K., Skarmoutsou, N. and Fakiri, E.M. (2013). Health Benefits of Probiotics: A Review. ISRN Nutrition, 2013, 481651. https://doi.org/10.5402/2013/481651

Klayraung, S., Viernstein, H. and Okonogi, S. (2009). Development of tablets containing probiotics: 
Effects of formulation and processing parameters on bacterial viability. International Journal of Pharmaceutics, 370(1-2), 54-60. https:// doi.org/10.1016/j.ijpharm.2008.11.004

Lele, V., Ruzauskas, M., Zavistanaviciute, P., Laurusiene, R., Rimene, G., Kiudulaite, D., Tomkeviciute, J., Nemeikstyte, J., Stankevicius, R. and Bartkiene, E. (2018). Development and characterization of the gummy-supplements, enriched with probiotics and prebiotics. CYTA Journal of Food, 16(1), 580-587. https:// doi.org/10.1080/19476337.2018.1433721

Lerner, A., Shoenfeld, Y. and Matthias, T. (2019) Probiotics: If it does not help it does not do any harm. really? Microorganisms, 7(4), 104. https:// doi.org/10.3390/microorganisms7040104

Lestari, L.A., Kusuma, W.I., Nurhayati, F., Kusuma, R.J. and Erwanto, Y. (2020). The viability of probiotic Lactobacillus acidophilus IFO 13951 and Bifidobacterium longum ATCC 15707 in gummy candies decreased during 4 weeks of storage. Food Research, 4(4), 1191-1195. https://doi.org/10.26656/ FR.2017.4(4).078

Li, D., Xie, H., Liu, Z., Li, A., Li, J., Liu, B., Liu, X. and Zhou, D. (2019). Shelf life prediction and changes in lipid profiles of dried shrimp (Penaeus vannamei) during accelerated storage. Food Chemistry, 297, 19. https://doi.org/10.1016/j.foodchem.2019.124951

Liao, L.K., Wei, X.Y., Gong, X., Li, J.H., Huang, T. and Xiong, T. (2017). Microencapsulation of Lactobacillus casei LK-1 by spray drying related to its stability and in vitro digestion. LWT - Food Science and Technology, 82, 82-89. https:// doi.org/10.1016/j.1wt.2017.03.065

Moayyedi, M., Eskandari, M.H., Rad, A.H.E., Ziaee, E., Khodaparast, M.H.H. and Golmakani, M.T. (2018). Effect of drying methods (electrospraying, freeze drying and spray drying) on survival and viability of microencapsulated Lactobacillus rhamnosus ATCC 7469. Journal of Functional Foods, 40, 391-399. https://doi.org/10.1016/j.jff.2017.11.016

Nagashima, A.I., Pansiera, P.E., Baracat, M.M. and Gómez, R.J.H.C. (2013). Development of effervescent products, in powder and tablet form, supplemented with probiotics Lactobacillus acidophilus and Saccharomyces boulardii. Food Science and Technology, 33(4), 605-611. https:// doi.org/10.1590/S0101-20612013000400002

Nurliyani, J.M., Harmayani, E., Ikawati, M. and Baliarti, E. (2015). Potency of Lactobacillus plantarum Dad13 and sweet potato (Ipomoea batatas) fiber as immunomodulator in rats infected with Salmonella typhimurium. Journal of Food Research, 4, 1-13. https://doi.org/10.5539/jfr.v4n3p1

Pamungkaningtyas, F.H., Mariyatun, M., Kamil, R.Z., Setyawan, R.H., Hasan, P.N., Wiryohanjoyo, D.V., Nurfiani, S., Zulaichah, E., Utami, I.S., Utami, T. and Rahayu, E.S. (2018). Sensory Evaluation of Yogurt-like Set and Yogurt-like Drink Produced by Indigenous Probiotic Strains for Market Test. Indonesian Food and Nutrition Progress, 15(1), 110. https://doi.org/10.22146/ifnp.31010

Pang, Z., Deeth, H., Sharma, R. and Bansal, N. (2015). Effect of addition of gelatine on the rheological and microstructural properties of acid milk protein gels. Food Hydrocolloids, 43, 340-351. https:// doi.org/10.1201/9780429290459

Pang, Z., Deeth, H., Sopade, P., Sharma, R. and Bansal, N. (2013). Rheology, texture and microstructure of gelatin gels with and without milk proteins. Food Hydrocolloids, 35, 484-493. https://doi.org/10.1016/ j.foodhyd.2013.07.007

Park, J.-M., Koh, J.-H. and Kim, J.-M. (2018). Predicting shelf-life of ice cream by accelerated conditions. Korean Journal for Food Science of Animal Resources, 38(6), 1216-1225. https:// doi.org/10.5851/kosfa.2018.e55

Rahayu, E.S, Cahyanto, M.N., Windiarti, L., Sutriyanto, J., Kandarina, T. and Utami, T. (2016). Effects of consumption of fermented milk containing indigenous probiotic Lactobacillus plantarum Dad13 on the fecal microbiota of healthy indonesian volunteers. International Journal of Probiotics and Prebiotics, 11(2), 91-98.

Rahayu, E.S., Rusdan, I.H., Athennia, A., Kamil, R.Z., Pramesi, P.C., Marsono, Y., Utami, T. and Widada, J. (2019). Safety assessment of indigenous probiotic strain Lactobacillus plantarum Dad-13 isolated from dadih using Sprague Dawley rats as a model. American Journal of Pharmacology and Toxicology, 14(1), 38-47. https://doi.org/10.3844/ ajptsp.2019.38.47

Rahayu, E.S., Yogeswara, A., Mariyatun, Windiarti, L., Utami, T. and Watanabe, K. (2015). Molecular Characteristics of Indigenous Probiotic Strains from Indonesia. International Journal of Probiotics and Prebiotics, 10(4), 109-116.

Santoro, M., Tatara, A.M. and Mikos, A.G. (2014). Gelatin carriers for drug and cell delivery in tissue engineering. Journal of Controlled Release, 190, 210 -218. https://doi.org/10.1016/j.jconrel.2014.04.014

Susanty, A. and Pujilestari, T. (2016). The effect of gelatin addition on physicochemical properties of Eucheuma cottoni jelly candy. Jurnal Riset Teknologi Industri, 8(16), 112-122. https:// 
doi.org/10.26578/jrti.v8i16.1559

Tari, A.I.N., Handayani, C.B. and Sudarmi, S. (2016).

Potential probiotic Lactobacillus plantarum indigenous Dad-13 on yoghurt with purple sweet potato extract supplementation to reducing diarrhea and free radicals. Jurnal Agritech, 36(1), 7-14. https://doi.org/10.22146/agritech.10677

Tari, I.N. and Handayani, C.B. (2015). Evaluation of antidiarrheal potential of indigenous Lactobacillus sp in purple sweet potato extract yogurt. Jurnal Teknologi Hasil Pertanian, 8(2), 63-70.

Tokatl, M., Gülgör, G., Bałder Elmac, S., Arslankoz Işleyen, N. and Özçelik, F. (2015). In vitro properties of potential probiotic indigenous lactic acid bacteria originating from traditional pickles. BioMed Research International, 2015, 315819. https:// doi.org/10.1155/2015/315819

Ullah, F., Othman, M.B.H., Javed, F., Ahmad, Z. and Akil, H. M. (2015). Classification, processing and application of hydrogels: A review. Materials Science and Engineering C, 57, 414-433. https:// doi.org/10.1016/j.msec.2015.07.053

Utami, T., Kasmiati, Harmayani, E. and Rahayu, E.S. (2016). Survival of Lactobacillus plantarum Dad 13 during spray drying and its application for yoghurt fermentation. International Research Journal of Biological Sciences, 5(2), 16-22.

Young, S., Wong, M., Tabata, Y. and Mikos, A.G. (2005). Gelatin as a delivery vehicle for the controlled release of bioactive molecules. Journal of Controlled Release, 109(1-3), 256-274. https:// doi.org/10.1016/j.jconrel.2005.09.023

Zhi, N.N., Zong, K., Thakur, K., Qu, J., Shi, J.J., Yang, J.L., Yao, J. and Wei, Z.J. (2018). Development of a dynamic prediction model for shelf-life evaluation of yogurt by using physicochemical, microbiological and sensory parameters. CYTA - Journal of Food, 16 (1), 42-49. https:// doi.org/10.1080/19476337.2017.1336572 